\title{
Chemical Modification and Structural Analysis of Protein Isolates to Produce Hydrogel using Whitemouth Croaker (Micropogonias furnieri) Wastes
}

\author{
Vilásia Guimarães Martins • \\ Jorge Alberto Vieira Costa • Srinivasan Damodaran • \\ Carlos Prentice
}

Received: 8 October 2010 /Accepted: 4 April 2011 /

Published online: 20 April 2011

(C) Springer Science+Business Media, LLC 2011

\begin{abstract}
Recovery and alteration of fish protein from wastes and its use has been regarded as a promising alternative to develop useful products once polymer gels have a high capacity of water uptake. This study aims to produce hydrogel, a super absorbent biopolymer from modified fish protein, in order to evaluate the protein structure. In the modified proteins, analyses of the extent of modification of the lysine residues, electrophoresis, and electrometric titration were performed. In the hydrogels were realized assays of swelling water. The proteins with more modifications were shown as $63.5 \%$ and $75.9 \%$ of lysine residues, from fish protein isolate obtained with alkaline and acid solubilization, respectively. The modified protein in that same rate presented 332.0 and 311.4 carboxyl groups. Accordingly, the hydrogel produced from alkaline and acid isolates reached a maximum water uptake in $24 \mathrm{~h}$ of 79.42 and $103.25 \mathrm{~g}_{\text {water }} / \mathrm{g}_{\mathrm{dry}}$ gel, respectively.
\end{abstract}

Keywords Fish $\cdot$ Waste $\cdot$ Hydrogel $\cdot$ Biopolymer $\cdot$ Super absorbent $\cdot$ Protein isolate

\footnotetext{
V. G. Martins $\cdot$ C. Prentice $(\bowtie)$

Laboratory of Food Technology, School of Chemistry and Food, Federal University of Rio Grande, Rio Grande, RS, Brazil e-mail: dqmprent@furg.br

J. A. V. Costa

Laboratory of Biochemical Engineering, School of Chemistry and Food,

Federal University of Rio Grande, Rio Grande, RS, Brazil

S. Damodaran

Department of Food Science, University of Wisconsin-Madison, 1605 Linden Drive, Madison, WI 53706, USA
} 


\section{Introduction}

Proteins are complex nitrogen substances with high molecular weight, which originate from amino acids from chemical or enzymatic hydrolysis. In agreement with authors as Reguly [1], Cheng et al. [2], Kristinsson and Rasco [3], and Slizyte et al. [4], the protein isolate is basically an extraction process of alkaline or acid solubilization and precipitation on isoelectric point, in order to obtain a product free from interference. The protein isolate can be manufactured from a variety of raw materials, such as soybean, milk, bean, or fish.

Waste from fish-filleting units is used in the production of fish meal or directly used in animal feed, but more frequently, it is discarded in close fish industries. In order to upgrade the wastes of the filleting, protein isolate from fish wastes has been receiving more attention in the last few years [5-8]. Research has been carried out in order to develop methods to convert these wastes into useful products [9-13].

Fish industry wastes are an important environmental contamination source. An important waste reduction strategy for the industry is the marketable recovery of fish wastes. Hydrolyzed fish wastes can be used in feeding fish or pig as well as fertilizer components. The three most common methods to apply aquatic waste are the manufacture of fishmeal/ oil, the production of silage, and the manufacture of organic fertilizer. The utilization of wastes is an important cleaner production opportunity for the industry, as it can potentially generate additional production and reduce disposal costs for these materials [14].

Animal proteins are rich in lysine, which is an essential amino acid with many functional properties, unlike vegetal proteins, such as soybean. The fish proteins tend to be very large, with an inherent capacity of water uptake. Rathna and Damodaran [15] reported that for the application in hydrogel, the physical properties of the fish polymers are higher than vegetable polymers. The lysyl residues $\left(-\mathrm{NH}_{2}\right)$ of proteins can be modified with carboxylic groups by reacting with ethylenediamine tetraacetic dianhydride (EDTAD) [16].

Chemical modification of proteins has been largely used to expose functional groups previously hidden into the protein chains, determining functional groups of enzymes and also helping to understand the action of drugs [17-21].

Many synthetic polymers have limited structural and functional properties, while the natural polymers are unique, with various functional and structural properties [22]. The mechanical and swelling properties of hydrogel by using natural polymers can be improved by chemical or physical modification of the functional groups [15, 23]. Modification does not alter the biodegradable and biocompatible characteristics of the proteins. Therefore, if suitable functionality can be imparted, the natural polymers could replace some potentially toxic synthetic polymers, which are unsuitable for many biological applications.

The material with high water capacity of retention has a large number of attributes that make them attractive in several applications. The basic property of water uptake has been suggesting the use of absorbent materials in many applications, such as, towel paper, surgery sponge, meat tray, bath rug, and medical patches [24].

Hydrogel is a light and wet class material, whose properties depend on the polymer net constructed and the water content [2]. One of the greatest challenges of science nowadays is the development of a new generation of biomaterials to improve human health and also to combat environmental problems related to pollution.

This work aimed the production of a protein biopolymer, through the chemical modification of fish protein isolate from Whitemouth croaker (Micropogonias furnieri) wastes and the structural characterization of these modified proteins. 


\section{Materials and Methods}

\section{Raw Material}

Whitemouth croaker (M. furnieri), obtained in fish processing industries of Rio Grande, Southern Brazil, was utilized as raw material. Croaker was transported in ice-filled containers to the laboratory at Federal University of Rio Grande, where processing took place. Then, the fish was immediately washed with chlorinated water, beheaded, eviscerated, and filleted. Wastes, such as viscera, bones, scales, skin, and head were grounded and placed in plastic containers and stored frozen at $-18^{\circ} \mathrm{C}$, pending use.

\section{Preparation of Fish Protein Isolate}

Two processes of chemical solubilization (acid and alkaline) and isoelectric precipitation to obtain the protein isolate from fish wastes were conducted. Samples were homogenized with distilled water (proportion 5:1, water:substrate). Reaction was conducted in a closed reactor, under stirring and controlled temperature. The alkalinizing agent was $1 \mathrm{~mol}^{-1} \mathrm{NaOH}$ and the acidifying agent was $1 \mathrm{~mol}^{-1} \mathrm{HCl}$. Acid solubilization was performed under $\mathrm{pH} 2.5$ for $20 \mathrm{~min}$ at $30^{\circ} \mathrm{C}$, and alkaline solubilization was carried out at $\mathrm{pH} 11.5$ for $20 \mathrm{~min}$ at $20^{\circ} \mathrm{C}$. After solubilization, the substrate was centrifuged at $7,500 \times \mathrm{g}$ for $15 \mathrm{~min}$. During centrifugation, the samples were separated in three phases: upper phase (neutral lipids) and bottom phase (insoluble proteins) were discarded, and the middle phase (soluble proteins) was subjected to isoeletric protein at $\mathrm{pH} 5.0$ until the precipitation and then centrifuged at $7,500 \times \mathrm{g}$ for $15 \mathrm{~min}$. The precipitate was stored at $-18^{\circ} \mathrm{C}$ and lyophilized afterwards [25].

\section{Modification of Fish Protein}

Chemical modification of the protein isolate was done with ethylenediamine tetraacetic dianhydride (EDTAD) in different concentrations, 0.05:1, 0.08:1, 0.1:1, 0.2:1, and 0.5:1 (EDTAD/protein). The EDTAD used was purchased from Sigma Chemical Co. The procedures were carried out as reported by other researchers [26]. The chemical modification procedure and analyses were done in triplicate. Protein solution of $1 \%$ was prepared at $\mathrm{pH} 12$ and incubated for $30 \mathrm{~min}$ at $65^{\circ} \mathrm{C}$, where the $\mathrm{pH}$ was adjusted with $1 \mathrm{~N}$ $\mathrm{NaOH}$. The solution was cooled to room temperature in an ice bath for $15 \mathrm{~min}$. The fish isolate reacted with solid EDTAD. During the 3-h reaction period, the protein solution was stirred constantly, and incremental amounts of EDTAD were added during the first 30-90 min, the reaction was kept at room temperature, and the $\mathrm{pH} 12$ of the protein solution was kept constant by adding $1 \mathrm{~N} \mathrm{NaOH}$. The reaction was finished when the $\mathrm{pH}$ remained constant for $30 \mathrm{~min}$. The $\mathrm{pH}$ of the protein solution was then adjusted to 4.5 to precipitate the protein. The suspension was centrifuged at $10,000 \times \mathrm{g}$ for $15 \mathrm{~min}$. The protein sediment was washed with water at $\mathrm{pH} 4.5$ and centrifuged. The final precipitate was quickly solved in water at $\mathrm{pH} \mathrm{7.0,} \mathrm{and} \mathrm{the} \mathrm{solution} \mathrm{was} \mathrm{dialyzed}$ exhaustively against deionized water to remove salts and lyophilized.

\section{Protein Determination}

Protein determination was performed by the method of Scopes [27] which uses purified samples, generally dialyzed and dried. Absorbance measurements are made at 205 and $280 \mathrm{~nm}$ and are usually necessary to examine the protein at two different concentrations, 
5-25 $\mu \mathrm{g} \mathrm{mL}^{-1}$ at $205 \mathrm{~nm}$, and $50-1000 \mu \mathrm{g} \mathrm{mL}^{-1}$ at $280 \mathrm{~nm}$. The absorbance values are then extrapolated to the original solution of protein, and the protein concentration is calculated from the following Equation (1):

$$
P(\mathrm{mg} / \mathrm{mL})=\frac{A_{205}}{27+120\left(\frac{A_{280}}{A_{205}}\right)}
$$

\section{Extent of Modification}

The extent of acylation was expressed as the percent of total lysyl residues modified. The lysine content of unmodified and acylated proteins was determined by the 2,4,6trinitrobenzenesulfonic acid (TNBS) method as described by Hall et al. [28]. According to this procedure, $1 \mathrm{~mL}$ of $4 \% \mathrm{NaHCO}_{3}$ was added $0.8 \mathrm{~mL}$ of a solution containing less than $5 \mathrm{mg}$ of protein, followed by the addition of $0.2 \mathrm{~mL}$ of TNBS solution $\left(12.5 \mathrm{mg} \mathrm{mL}^{-1}\right)$. This solution was incubated at $40^{\circ} \mathrm{C}$ for $2 \mathrm{~h}$, followed by the addition of $3.5 \mathrm{~mL}$ of concentrated $\mathrm{HCl}$, and further, the tubes were stoppered and incubated at $100^{\circ} \mathrm{C}$ for $3 \mathrm{~h}$. After cooling, the volume was enhanced to $10 \mathrm{~mL}$ with deionized water. The solution was extracted twice with equal amounts of ether, from which the aqueous solution was separated, and the tube was unstoppered and kept at $40^{\circ} \mathrm{C}$ to allow the residual ether to evaporate. The absorbance of the yellow ( $\varepsilon$-TNP lysine) solution was measured at $415 \mathrm{~nm}$. The amount of reactive lysyl residues in the acylated and unacylated protein was determined from the standard curve constructed using lysine.

\section{Electrometric Titration}

All electrometric titrations were performed at room temperature $\left(25 \pm 2{ }^{\circ} \mathrm{C}\right)$ using $0.1 \%$ modified protein in $6 \mathrm{M}$ guanidine hydrochloride essentially as described elsewhere [29]. The titrant used was $0.5 \mathrm{M} \mathrm{NaOH}$ and $0.5 \mathrm{~N} \mathrm{HCl}$. Typically, a $40-\mathrm{mL}$ aliquot of a modified protein solution in $6 \mathrm{M}$ guanidine hydrochloride at $\mathrm{pH} 2$ was placed in a titration vessel. To this solution were added $25 \mathrm{~mL} \mathrm{~L}^{-1}$ aliquots of $\mathrm{NaOH}$. After each addition, the $\mathrm{pH}$ of the protein solution was recorded using a titrimeter (Model 450, Fisher Scientific Instruments) equipped with a combination $\mathrm{pH}$ electrode with a silver/silver chloride reference electrode. This addition was done until $\mathrm{pH}$ reach 9. A titration curve for $6 \mathrm{M}$ guanidine hydrochloride (blank) was also performed under identical conditions. The titration curve of the blank was subtracted from the protein solution titration curve to obtain the titration curve of the protein alone. The number of moles of carboxyl groups per mole of protein was determined from the number of moles of $\mathrm{NaOH}$ consumed by $10^{5}$ gmol of protein for titration from $\mathrm{pH} 2.0$ until the isoionic point of the protein which was the $\mathrm{pH}$ of the modified protein solution after exhaustive dialysis against deionized water.

\section{Electrophoresis}

Sodium dodecyl sulfate polyacrylamide gel electrophoresis (SDS-PAGE) with a lineargradient slab gel at $12 \%$ was performed according to the method of Laemmli [30]. All samples were treated with $5 \%$ of $\beta$-mercaptoethanol. Gels were run at a constant voltage of $0.02 \mathrm{~A}$ for about $1 \mathrm{~h}$ and later it was increased to $0.04 \mathrm{~A}$ for more $1 \mathrm{~h}$. The staining of the gels occurred in a solution of methanol $50 \%(v / v)$, acetic acid glacial $6.8 \%(v / v)$, and 
Coomassie Brilliant Blue- $\mathrm{R}\left(12.5 \mathrm{mg} \mathrm{mL} \mathrm{m}^{-1}\right)$ for $3 \mathrm{~h}$. The gels were distaining in a solution of acetic acid 7.5\% $(v / v)$ and methanol $5 \%(v / v)$, renovating the solution until a clear gel was obtained. The molecular weight marker proteins were purchased from Sigma Chemical Co.

Cross-linking by Glutaraldehyde

A $10 \%(w / v)$ dispersion of the modified protein solution was adjusted to $\mathrm{pH} 9$ by adding $1 \mathrm{M} \mathrm{NaOH}$ solution. The $25 \%$ aqueous solution of glutaraldehyde $25 \%$ was added in a rate of $0.02: 1$ (glutaraldehyde/protein, $w / w$ ). After the addition of the cross-linking agent, the solution was mixed vigorously to homogenize it, and the solution was allowed to cure at room temperature overnight. After this step, the mixture was dried in an oven at $40^{\circ} \mathrm{C}$ for $48 \mathrm{~h}$ and grounded [24].

\section{Swelling Kinetics}

Water uptake of gels was determined by the Tea Bag method. A gel sample of 20-30 mg was placed in a heat-sealable pouch $(4 \times 6 \mathrm{~cm})$ made from a nylon and paper complex (Bolmet Inc.) The bag was dipped in water for $24 \mathrm{~h}$, centrifuged at $214 \times \mathrm{g}$ for $5 \mathrm{~min}$ in a clinical centrifuge, and the increase in weight was measured immediately. All swelling studies were carried out at room temperature $\left(25 \pm 2^{\circ} \mathrm{C}\right)$. The water uptake of gel was indicated by the weight of water absorbed divided by the weight of dried gel [26]. The wet pouch with swollen gel was dried in an oven at $105^{\circ} \mathrm{C}$ to constant weight. Each data point represents an average value of three gel samples.

\section{Results and Discussion}

\section{Extent of Modification}

The chemical modification of lysyl residues with a tetracarboxylic dianhydride introduces a large number of carboxyl groups into a protein molecule. These added carboxyl groups, in addition to causing extensive unfolding of the protein molecule via intramolecular electrostatic repulsion, would impart a polyanionic character to the protein with numerous sites for water binding.

Figure 1 shows the extent of modification of lysine residues in different concentrations of EDTAD. It can be observed that when more EDTAD is used, the modification degree is higher. The isolate obtained from acid solubilization, in the rate EDTAD/protein (0.5), attained $72.4 \%$ of lysine residue modification, while the isolate obtained from alkaline solubilization reached, at the same condition, $63.5 \%$ of modification. In a similar study, however, using alkaline protein isolate from meat fish in a chemical modification with EDTAD/protein (0.5) was found to have a modification of $75.9 \%$ of lysine residues [26]. Using soy protein isolate, it reached a modification of $90 \%$ of lysine residues when EDTAD/protein (0.5) was used, which shows that soy proteins are more sensitive to chemical modification [24].

As the lysine residues are essential for the crosslink of modified proteins with glutaraldehyde, then we defined the maximum values for extent of modification as the optimum, in which they reached values of $63.5 \%$ and $72.4 \%$ for the alkaline and acid protein isolate, respectively, both in the concentration of 0.5 (EDTAD/protein). 
Fig. 1 Extent of modification of the (filled circle) acid and (filled square) alkaline fish protein isolates

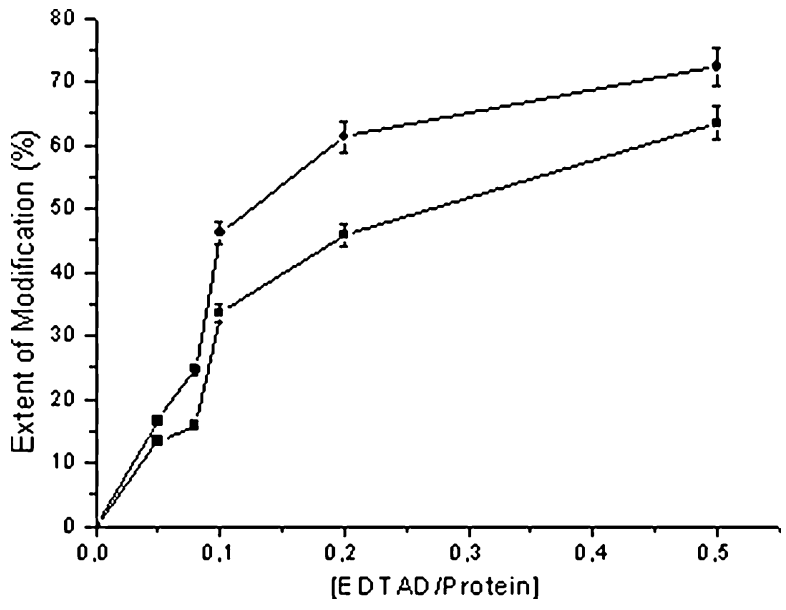

The water uptake of the gel can be increased further by increasing the extent of modification of lysyl groups. However, since lysyl residues are also required for crosslinking, the protein molecules with glutaraldehyde, a certain percentage of the lysyl groups should be left unmodified. On the other hand, if the amount of lysine residues was high, it should not be possible to have much water uptake either, as there are many lysine residues, it means many disposal sites to link water inside the polymer net, but at the same time, there is no space for swelling water. Therefore, the optimum extent of modification of lysyl groups depends on the total number of lysyl residues in a protein $[16,24]$.

\section{Electrophoresis}

Figure 2 shows the analysis of SDS-PAGE for the unmodified protein and chemically modified protein. The electrophoresis profiles of all EDTAD-modified isolated show significant amounts of high molecular weight protein polymer that could not penetrate the stacking and separating gel. According to Hwang and Damodaran [26], the polymerization must be due primarily to the formation of intermolecular cross-linking by the bifunctional EDTAD. The formation of other covalent bonds might be produced under alkaline reaction conditions used for modification.

These samples were treated with $5 \%$ of $\beta$-mercaptoethanol and $10 \%$ SDS. The high molecular weight polymers present in Fig. 2 cannot be due to disulfide cross-linking. They must be due to protein cross-linking by the bifunctional EDTAD. Previously, it was demonstrated that protein cross-linking by EDTAD at low protein concentration occurs only when the protein molecules are in an oligomeric or aggregated state [24]. It appears that a $\mathrm{pH} 12$ and $65^{\circ} \mathrm{C}$ pre-treatment is not sufficiently drastic to dissociate the myofibrils and to prevent protein-protein cross-linking by the bifunctional EDTAD.

It was observed a decrease in the intensification of protein bands with increasing extent of modification in the SDS-PAGE (Fig. 2), which is not due to a loss of protein resulting from hydrolysis, but the result of poor ability that modified proteins have to absorb the color of solution. The same amount of the protein was applied for each line for electrophoresis. 


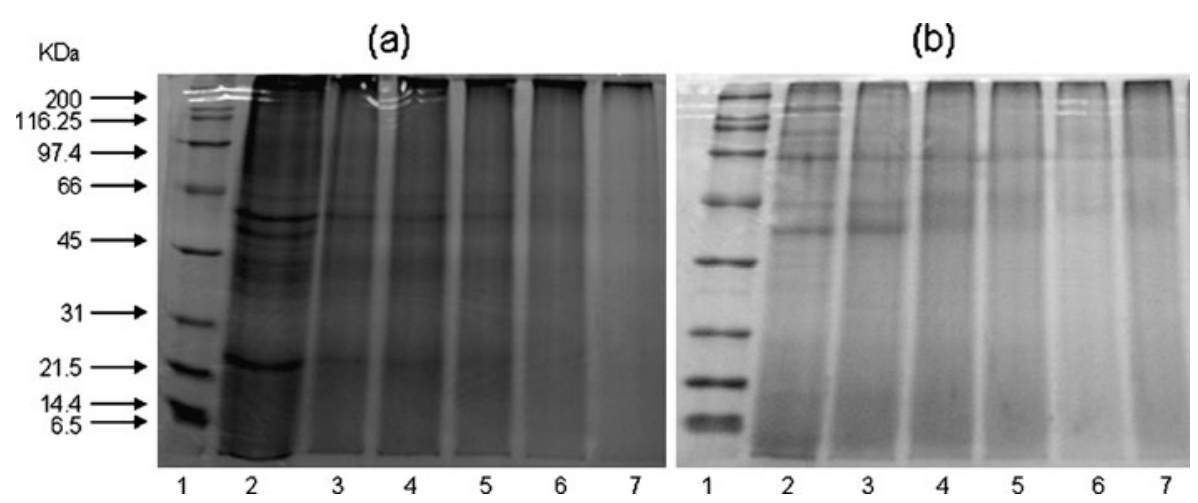

Fig. 2 SDS-PAGE of unmodified and EDTAD-modified fish protein isolates. Alkaline isolate (a) and acid isolate (b). Sample 1 is the molecular weight markers; sample 2 is the alkaline isolate and acid isolate, respectively; sample 3 is modified 1:0.05 (protein/EDTAD); sample 4 is modified 1:0.08; sample 5 is modified 1:0.1; sample 6 is modified 1:0.2; sample 7 is modified 1:0,5

\section{Electrometric Titration}

To make sure that the EDTAD reaction with the fish isolates, under the conditions in use modified the lysine residues and allowed the introduction of carboxyl groups, it was performed the electrometric titration. Results obtained are presented in the Fig. 3, for the alkaline and acid isolates, respectively.

It was observed that in the extent of modification, the more EDTAD is added during the process, the higher is the amount of lysyl-modified residues. This modification is closely connected with the amount of carboxyl groups added in the molecule. According to Hwang and Damodaran [24], the chemical modification of lysyl residues with tetracarboxyl dianhydride enables the introduction of a great number of carboxyl groups into the protein molecule. This addition of carboxyl groups induces unfolding of protein molecule through intramolecular electrostatic repulsion, which leads to a polyanionic character to the protein with many links to the water.

No modified alkaline isolate showed 124 carboxyl groups per $10^{5}$ gmol of protein, and it can be observed in Fig. 3 that the larger the extent of modification (modified lysyl residues)

Fig. 3 Numbers of carboxyl groups introduced in the unmodified and EDTAD-modified alkaline and acid protein

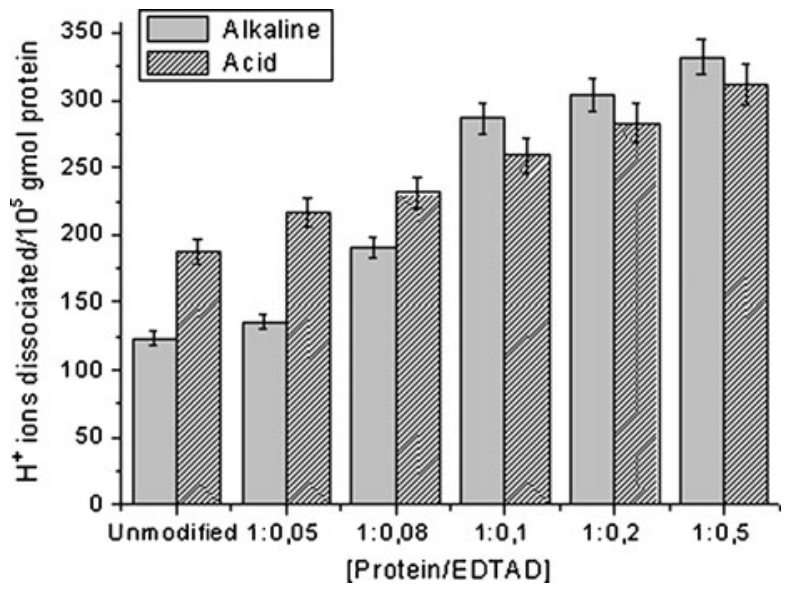


of the hydrolysate, the higher are the carboxyl groups. The hydrolysate that obtained a modification of $63.5 \%$ of lysyl residues reached an amount of 332 carboxyl groups per $10^{5}$ gmol of protein.

The modified isolate produced from acid isolate (Fig. 3) showed less carboxyl groups when compared with modified alkaline isolate. The modified acid isolated 1:0.5 (protein:EDTAD, w/w) showed lysyl-modified residues $(72.4 \%)$ higher than alkaline; however, it attained a maximum of 311.4 carboxyl groups.

Correlation between the content of lysyl-modified residues and the amount of carboxyl groups from the EDTAD is a result of the extent of such modification. The acid isolate showed $0.494 \mathrm{mg}$ of lysine and 187.98 carboxyl groups, while the modified isolate $72.4 \%$ obtained $0.136 \mathrm{mg}$ of lysine and 311.4 carboxyl groups. Thus, the alkaline isolated showed $0.488 \mathrm{mg}$ of lysine and the modified $63.5 \%$ obtained $0.178 \mathrm{mg}$ of lysine and 332 carboxyl groups. Hwang and Damodaran [24] verified the amount of carboxyl groups introduced in soybean modified isolate with EDTAD, noticeably, for the unmodified isolate and modified EDTAD $49 \%$ and $91 \%$, while the amount of carboxyl groups were 146, 212, and 295 , respectively.

EDTAD is a bifunctional reagent. Therefore, in aqueous solutions, reaction of EDTAD with protein lysyl residues can follow two different routes. In the first reaction, one molecule of EDTAD reacts simultaneously with two lysyl residues from two protein molecules or two polypeptide chains of protein to form linkage. When the reaction proceeds by first reaction, the result is the incorporation of only one carboxyl group per lysyl residue. In the second reaction, one molecule of EDTAD reacts with one lysyl residue and one molecule of water. In this reaction, three carboxyl moieties per lysyl residue are incorporated into the protein. Then, according to the results obtained in this study, we can say that the chemical reaction with EDTAD followed the second reaction because a great increase in the number of carboxyl groups was obtained, while the amount of lysyl residues were reduced in the modified isolate. It was not possible, however, to specify the exact amount of carboxyl groups incorporated per lysyl residue because the amount of lysyl residues in each modified isolate was not identified.

\section{Swelling Properties}

The swelling properties of hydrogels produced through the chemical modifications of protein isolates were evaluated. Figures 4 and 5 show the behavior of water uptake of the hydrogels in different degrees of chemical modification.

It was observed that the larger the chemical modification degree, the higher the capacity of the hydrogel to absorb water. This procedure occurs once the amount of EDTAD is increased and more lysyl residues are modified; therefore, the hydrogel has more link sites and space to capture water inside tridimensional net. As explained previously, if the protein molecule has plenty of available lysine, consequently, there are many links for the water, but there is no space for the swelling inside the polymeric structure.

The hydrogels produced from acid and alkaline isolates obtained a maximum water uptake as time went on, but more than $70 \%$ of the capacity of water absorb was seen in the first hours of gel immersion in water. The rate of swelling of hydrogels is influenced by a number of factors, including the rate of ionic exchange [31], rate of water diffusion, and the rate of polymer relaxation [31-33]. Initially, water uptake is governed only by the diffusion of water molecules into the gel matrix. Data in Figs. 4 and 5 show that swelling from the glassy state increased dramatically in the first hours of swelling. At this stage, the protein molecules became hydrated, and protein-protein interactions were disrupted by the 
Fig. 4 Water uptake kinetics of hydrogels produced from acid fish protein isolate. Filled square acid; filled circle acid 1:0.05 (protein:EDTAD, $w / w)$; filled triangle acid 1:0.08; inverted filled triangle acid 1:0.1; filled diamond acid 1:0.2; left pointing filled triangle acid $1: 0.5$

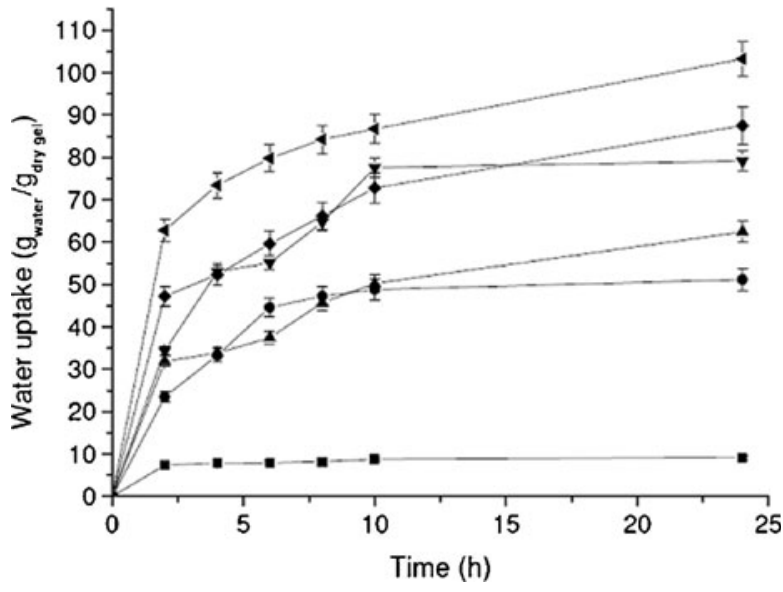

absorbed water. Since the polymer relaxation rate during hydration is generally slower than it is the rate of diffusion of water into the gel, the polymer relaxation process is often the rate-limiting step in the swelling.

The hydrogel processing from acid isolate showed a higher capacity of water uptake when compared with the hydrogels produced from alkaline isolate; this occurred because the modified acid presented a higher extent of modification of lysyl residues.

The unmodified acid isolate reached a maximum swelling of $9.22 \mathrm{~g}_{\text {water }} / \mathrm{g}_{\text {dry gel }}$ in $24 \mathrm{~h}$, and the modified isolate EDTAD/protein 0.05 reached $51.17 \mathrm{~g}$ water $/ \mathrm{g}_{\text {dry gel }}$. These values show that even with the minimum modification of lysyl residues, it is possible to increase in the water uptake, in this case, approximately five times the initial value. The same occurred for the prepared hydrogel from alkaline isolate, where in spite of a smaller chemical modification, it reached a considerable increase in the swelling of the hydrogels. The diffusion through the polymers is mainly influenced by ionic interactions and the crosslink density during the construction of polymeric net. The increase in the crosslink density reduces the swelling as well as the diffusion for the improvement of net stability [34].

The maximum value of water uptake for the hydrogel prepared with acid isolate was $103.25 \mathrm{~g}_{\text {water }} / \mathrm{g}_{\text {dry gel }}$ when the modified isolate $0.5($ EDTAD/protein, $w / w)$ was used. For

Fig. 5 Water uptake kinetics of produced hydrogels from alkaline fish protein isolate. Filled square alkaline; filled circle alkaline 1:0.05 (protein:EDTAD, w/w); filled triangle alkaline 1:0.08; inverted filled triangle alkaline 1:0.1; filled diamond alkaline 1:0.2; left pointing filled triangle alkaline 1:0.5

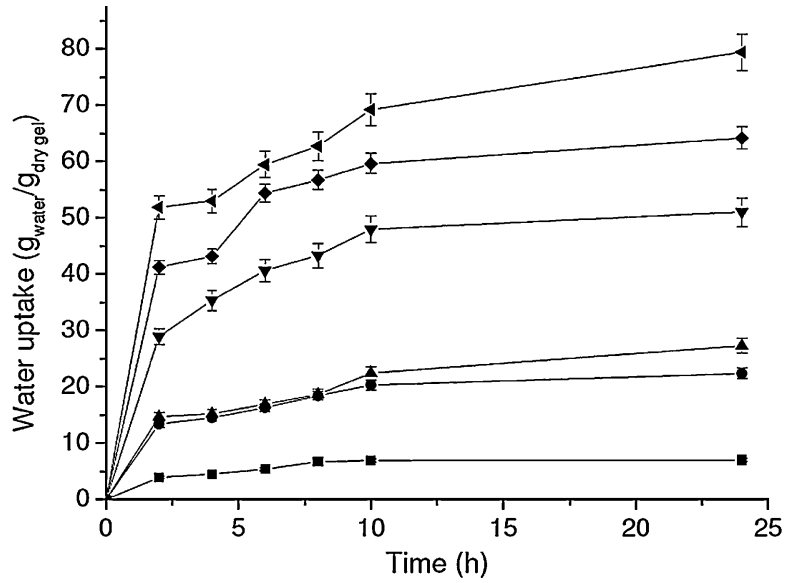


the hydrogel from alkaline modified, the maximum of swelling was $79.42 \mathrm{~g}_{\text {water }} / \mathrm{g}_{\mathrm{dry}}$ gel, in the same conditions of acid isolate above.

Hwang and Damodaran [26] produced hydrogel from fish alkaline isolate and evaluated the water uptake of the hydrogel in two ways, just with S-S cross-linking which swelled around $580 \mathrm{~g}_{\text {water }} / \mathrm{g}_{\mathrm{dry} \text { gel }}$ and with glutaraldehyde addition of 0.01 (glutaraldehyde/protein). This same hydrogel absorbed approximately $220 \mathrm{~g}_{\text {water }} / \mathrm{g}_{\mathrm{dry}}$ gel. However, the increase in cross-linking density impaired the water uptake of gels. Thus, if the gels were to be used to absorb water under certain applied pressure, the glutaraldehyde cross-linking hydrogel was preferable to the $\mathrm{S}-\mathrm{S}$ only cross-linking gel.

The hydrogel produced by Hwang and Damodaran [26] from fish muscle showed higher values of water uptake $\left(220 \mathrm{~g}_{\text {water }} / \mathrm{g}_{\text {dry gel }}\right)$ than those found in this work $(79.42$ and $103.25 \mathrm{~g}_{\text {water }} / \mathrm{g}_{\mathrm{dry}}$ gel $)$, from modified acid and alkaline isolated, respectively. Therefore, it should be emphasized that the isolates used in this study had an amount of fat between $7 \%$ and $9 \%$, and probably because of that, the values reached for water uptake were not higher. In the study of Hwang and Damodaran [26], the amount of fat was around $1 \%$.

In general, the synthesis of a protein-based hydrogel involves essentially three steps: first, dissociation and partial denaturation of protein; second, modification of lysyl residues with ethylenediaminetetraacetic dianhydride, or with any other tetracarboxylic dianhydrides, to cause unfolding and to enhance the polyanionic character of the protein; and third, cross-linking of the modified protein with a bifunctional reagent to obtain an insoluble polymer network capable of absorbing a large amount of water.

\section{Conclusion}

Results corroborate the possibility to produce hydrogel, a biopolymer with great capacity of water uptake from protein isolates of Whitemouth croaker (M. furnieri) wastes. This is a hopeful alternative to increase the productivity in the fish plants, because at the same time, as the residue is being treated, another product is made.

Acknowledgements Authors wish to thank The Coordination for Improvement of Higher Education Personnel in Brazil (CAPES) and National Council for Scientific and Technological Development of Brazil (CNPq) for financial support to carry out experiments.

\section{References}

1. Reguly, J. C. (1983). Biotecnologia dos processos fermentativos. Pelotas: Ed Universitária.

2. Cheng, G. X., Liu, J., Zhao, R. Z., \& Yao, K. D. (1998). Journal of Applied Polymer Science, 67, 983988.

3. Kristinsson, H. G., \& Rasco, B. A. (2000). Journal of Agricultural and Food Chemistry, 48, 657-666.

4. Slizyte, R., Dauksas, E., Falch, E., Storro, I., \& Rustad, T. (2005). Process Biochemistry, 40, 2021-2033.

5. Bechtel, P. J., Sathivel, S., \& Oliveira, A. C. M. (2005). Alkali extracted protein fractions from salmon byproducts. Annual IFT Meeting 2005 New Orleans, Louisiana.

6. Batista, I., Pires, C., Nelhas, R., \& Godinho, V. (2006). Acid and alkaline-aided protein recovery from Cape Hake by-products. Wageningen: Wageningen Academic Serial.

7. Chen, Y. C., \& Jaczynski, J. (2007). Journal of Agricultural and Food Chemistry, 55, 9079-9088.

8. Røkaeus, S., \& Undeland, I. (2007). Production of protein isolates from whole and gutted herring (Clupea harengus) using a pH shift method. Lisboa: WEFTA. 
9. Guerard, F., Guimas, L., \& Binet, A. (2002). Journal of Molecular Catalysis. B, Enzymatic, 19-20, 489498.

10. Coello, N., Montiel, E., Concepcion, M., \& Christen, P. (2002). Bioresource Technology, 85, 207-211.

11. Laufenberg, G., Kunz, B., \& Nystroem, M. (2003). Bioresource Technology, 87, 167-198.

12. Kato, S., Kunisawa, N., Kojima, T., \& Murakami, S. (2004). Journal of Chemical Engineering Japan, $37,863-870$.

13. Gebauer, R., \& Eikebrokk, B. (2005). Bioresource Technology, 97, 2389-2401.

14. Arvanitoyannis, I. S., \& Kassaveti, A. (2008). Int Journal of Food Science and Technology, 43(726), 745.

15. Rathna, G. V. N., \& Damodaran, S. (2002). J. Apll. Polym. Sci., 85, 45-51.

16. Rathna, G. V. N., \& Damodaran, S. (2001). Journal of Applied Polymer Science, 81, 2190-2196.

17. Rathna, G. V. N., \& Gunasekaran, S. (2004). Polymer International, 53, 1994-2000.

18. Léonard, R., Lhernould, S., Carlué, M., Fleurat, P., Maftah, A., \& Costa, G. (2005). Glycoconjugate J., $22,71-78$.

19. Zhang, S.-P., \& Ping, W. (2006). Shengwu Jiagong Guocheng, 4, 4-8.

20. Kurniawan, L., Qio, G. G., \& Zhang, X. Q. (2007). Biomacromolecules, 8, 2909-2915.

21. Solanki, K., Shah, S., \& Gupta, M. N. (2008). Biocatalysis and Biotransformation, 26, 258-265.

22. Amiya, T., \& Tanaka, T. (1987). Macromolecules, 20, 1162-1164.

23. Lu, G. H., \& Chen, T. C. (1999). Journal of Food Engineering, 42, 147-151.

24. Hwang, D. C., \& Damodaran, S. (1996). Journal of Agricultural and Food Chemistry, 44, 751-758.

25. Martins, V. G., Costa, J. A. V., \& Prentice-Hernández, C. (2009). Quím. Nova, 32, 61-66.

26. Hwang, D. C., \& Damodaran, S. (1997). Journal of the American Oil Chemists' Society, 74, 1165-1171.

27. Scopes, R. K. (1974). Analytical Biochemistry, 59, 277-282.

28. Hall, R. J., Trinder, N., \& Givens, D. I. (1973). The Analyst, 98, 673-686.

29. Nozaki, Y., \& Tanford, C. (1967). Journal of the American Chemical Society, 89, 736-749.

30. Laemmli, U. K. (1970). Nature, 227, 680-685.

31. Gehrke, S. H. (1993). In advances in polymer science 110 - responsive gels: volume transitions II. In: K. Dusek (Ed.). Berlin: Springer.

32. Okuyama, Y., Yoshida, R., Sakai, K., Okano, T., \& Sakurai, Y. (1993). J. Biomater. Sci. Polym. Ed., 4, 545-556.

33. Dave, A., Vaishnav, U., Desai, R., Shah, A., Ankleshwaria, B., \& Mehta, M. (1995). Journal of Applied Polymer Science, 58, 853-859.

34. Pal, K., Banthia, A. K., \& Majumdar, D. K. (2007). J. Mater. Sci. Mater Med., 18, 1889-1894. 